\title{
Notes and Documents
}

TWELFTH-CENTORY NOTEB.

\section{An Unknown Mistress of Henry $I$.}

A conious story is incidentally told in a record of the days of Henry III entered in the Testa de Nevill (p. 352). Gilbert de Gaunt gives it in his reasons why he should not be called upon to pay on certain knight's fees credited to him at the exchequer. Among the exemptions he seeks is one for three fees representing an estate which his family claimed, bat had never been able to regain. According to him, Henry I, having seduced a sister of Walter de Gaunt, his ancestor, arbitrarily took this estate from her brother and handed it over to her as a provision for life. If the story is true-and it would scarcely be invented-it reveals ono of the very shabbiest tricks of the so-called 'Lion of Justice.' 1

On the death of the grantee (temp. Henry II) the estate, instead of reverting to the family, was granted out anew by that king. Agnes de la Roche, holding under this fresh grant, was impleaded till her death by Gilbert de Grunt, the complainant's father. ${ }^{2}$ But when she died, Henry III re-granted the land to his sister, the Queen of Scotland, and is alleged to have stopped Gilbert's action against her by a writ of prohibition. When the queen died, and Stephen de Segrave obtained a grant of the disputed estate, the indefatigable Gilbert renewed his action and impleaded him to the day of his death.s

This document is also of interest for its reference to the return of his knight's fees sent in by earl Simon in 1166, illustrating the

1 Rex Henricus primus cepit istas torras pro voluntate sua do dicto Waltero, of tradidit eas cuidam sorori dicti Walteri, cum qua idem rex fecit voluntatom suam, ad so sustinendam in vita sua.

- This statement is confrrued by a case in 'Bracton's Note-Book' (ed. Maitland, i. 186 , ii. 8), which reveals to as Agnes shirking the action in 1224 : Gilebertus do Gaunt per attornatum sutum optulit se . . verstus, Agnetem do Rupe . . de placito terre, etc.

- Dominus rex qui runc cst tradilit . . dichas terras Stophano de Segrave, quem Gibbertus de Gaunt pater istitus Gilberti implacitavit usque ad mortem ipsius. The word ipsius leaves us in doubt as to whose death is meant, but they both died about the same time (1241).

- Ilem heredes subscriptorum qui rominati sunt in carla quam comes Simon facit domino $R$. Henrico secundo contradicit (sic) fooda contenta in predicla carta. 
importance of these 'cartæ' for reference, long afterwards, in disputes. The date of the document is thus determined. It belongs to the time when William de Lungespee held the Haye fief (jurc uxoris), that is, $1215-1250$, and it is subsequent to the death of the claimant's father in $26 \mathrm{Hen}$. III. 'It may therefore be assigned to 1241-1250. Now we know that the claimant paid on his knight's fees towards the aid for marrying the king's deughter in 29 Hen. III (1245), and it may therefore fairly be assigned to that occasion.

\section{Robert of Bampton.}

So much confusion has prevailed concerning this man, whose rebellion against Stephen in 1186, with the siege of his castle by the king, is related at some length in the 'Gesta Stephani,' that it may be well to establish his identity in a brief note. Miss Norgate speaks of him as 'Robert of Bathenton'

or Bakington. In the 'Gesta Steph.' (Sewell), p. 18, the name of the place is Batthentona, which Lappenberg and Mr. Freeman render by Bathenton, in Deron ( $\mathrm{Mr}$. Sewell, the editor of the 'Gesta Steph.,' rendered it Bath). But while two MSS. of Henry of Huntingdon have 'Bathentun' three others hare 'Bachentun' or 'Bakentun' (Arnold, p. 259, note 6. In the index Mr. Arnold suggests 'Bagington? Bathampton ?')

The latest editor of the 'Gesta,' Mr. R. Howlett, renders 'Batthentona' unhesitatingly as 'Bathampton' (which adjoins Bath). ${ }^{6}$

To Lappenberg belongs the credit of having rightly identified it with the 'Baentona' (now Bampton, co. Devon) of Domesday, and its holder with Robert de Baentona, who occurs in the pipe roll of Henry I (pp. 153-4). ${ }^{7}$ Polwhele (iii. 377-8) says that Bampton, in Domesday Baentonc, has been spelt Baunton, Badentone, Bathamton, Bathrum-ton, and Bathermton (being named from its river). It was part of the great Domesday barony of Walter de Dousi, whom, here and elsewhere, Robert had succeeded (he is said, bat I know not on what evidence, to have been Waiter's son). Dugdale states that William Paynel 'married Jalian the daughter of Robert de Bahantune,' but his evidence is a grant of Bridgwater church by her son Fulk Paynel 'de Bahantune,' in which he speaks of his mother as matris meac Julianae de Bahaintune, but does not mention Robert. There is, however, no question that the barony of Bampton descended to the Paynels. The 'Gesta' describes Robert as nec honoris terrarum exigui, and states that he was sentenced to forfeiture by Stephen's curia. The latter statement is confirmed by a

- England under the Argeoin Kirgs, i. 284.

- Pp. 18-20. Bnt he has since, in his edition of Robert do Torigni, p. 129, esserted that 'Bachentwne,' according to Domesday, is in Wiltshire. The place in Dovonshire supposed to represent 'Bachentwn' is called 'Bachestane' in the Survey.

'Mr. Freeman refers to him as having identifled the locality as 'a place in Devon.' 
charter I have seen, in which Stephen, some years later, grants away the estates of Robert 'de Baentona' in another county as an escheat.

\section{III. 'I'le alleged intasion of England by Honry Fitzempress in 1147.}

When Mr. Richard Howlett, in the preface to his edition of the 'Gesta Stephani' for the Rolls series, announced that we were indebted to its 'careful author' for the knowledge of an invasion of England by Henry Fitzempress in 1147, ' anrecorded by any other chronicler,' and endeavoured at considerable length to establish this proposition, ${ }^{8}$ it was received, from all that I can learn, with general incredulity. As, however, in the volume which he has just edited, he reiterates his belief in this alleged invasion, ${ }^{9}$ it becomes necessary to examine in detail the evidence for a discovery so anthoritatively announced in the pages of the Rolls series.

The accepted view of Henry's movements has bitherto been that, by his father's permission, in the autumn of 1142 he accompanied the earl of Gloucester to England ; that he remained there about four years ; that, by his father's wish, at the end of 1146 or beginning of 1147 he returned from England; that he then spent two years and four months over sea ; that in the spring of 1149 he again came to England, and was knighted at Carlisle by the king of Scots on 22 May. As to the above long visit, commencing in 1142, Gervase of Canterbury is our chief authority, but the other chroniclers (omitting for the present the 'Gesta Stephani') harmonise well with his account. Gervase and Robert of Torigni alike mention but one arrival of Henry (1142) and one departure (1146 or 1147), thus distinctly implying there was then only one risit-namely, that visit which Gervase tells us lasted four years. The only slight discrepancy between Gervase and Robert is found in the date of Henry's departure. Robert places that event under 1147, and mentions that Henry visited Bec 29 May in that year. There is also, Mr. Howlett has pointed out, charter evidence implying that Henry was back in Normandy in March or April. Now Gervase says distinctly that he was away from England two years and four months. The chroniclers, Gervase included, say that he returned to England in the middle of May 1149. Counting back the two years and four months, this would bring us to January 1147 as the date of his departure from-England. But there is a charter of his to Salisbury cathedral, tested, as Mr. Howlett observes, at Devizes'13 April, 1149. If this evidence (I do not know if or where the original charter, or even its text, is preserved) be trustworthy it would take us back to December 1146 instead of January 1147. It is easy to see how Gervase may have included

- Chronicles, Stephen, Henry II, Richard I, vol. iii. pp. xvi-xx, 130.

- Ib. vol. iv. pp. xxi-xxii, 
in 1146 , and Robert in 1147 , an event which appears to have taken place about the end of the one or beginning of the other year.

Much has been made of the alleged circumstance that Gervase assigns the earl of Gloucester's death to 1146, whereas he is known to have died in 1147. But reference to his text will show that he does nothing of the kind. Writing of Henry's departure at the close of 1146, he tells us that the earl was destined never to sce him agrin, for he died in November [i.e. November 1147]. He is here obviously anticipating.

Such being the evidence on which is based the accepted view of Henry's movements, let us now turn to the 'Gesta Stephani.' Though Mr. Howlett's knowledge of the period is great and quite exceptional, I cannot but think that he has been led astray by his admiration for this fascinating chronicle. Miss Norgate sensibly obserres that 'there must be something wrong in the story' as actually preserved in the 'Geste,' ${ }^{10}$ but Mr. Howlett, unwilling to admit the possibility of error in his chronicle, boldly asserts that the "romantic account'" of Henry's adventures which it contains does not refer to his visit in 1149 , but to a hitherto unknown invasion in 1147. He appears to imagine that the only objection in accepting this story is found in the fact that Henry was bat just fourteen at the time. ${ }^{18}$ But this is not so. Putting aside this objection, as also the silence of other chroniclers, there remains the chronological difficulty. How is the alleged visit to be fitted in? Its inventor, who suggests 'about April 1147 ' for its date, must first take Henry back to Normandy (why or when he does not even suggest) and then bring him back to England as an invader, neither his alleged going or coming being recorded by any chronicler. 'Then he assigns to his second return to Normandy (after the alleged invasion) the only passages in Gervase and Robert which speak of his returning at all. Surely nothing could be more improbable than that Henry should rush back to Englend just after he had left it, and had returned to his victorious father, and this at a time when his cause seemed as hopeless there as it was prosperous over the see.

The evidence of the 'Gesta Stephani' would have indeed to be beyond question if we are to accept, on its sole authority, so improbable \& story. But what does that evidence amount to? The 'Gesta,' unlike other chronicles, not being arranged chronologically under years, the only definite note of time here afforded in its text is found in the passage, Consuluit [Henricus] et avunculum (sic) Glaorniae comitem, sed ipse suis sacculis aride incumbens, rebus tantum sibi necessarizs occurrere maluit. ${ }^{13}$

10 England under the Argevin Kings, i. 377. "Ib.

11 "The invasion of England by Henry in 1147, when he was but a boy of fourteen, a piece of history which has hitherto been rejected solely on the ground of impro. bability.'-Prefaco (ut supra), p. zxi.

4 Gata (ed. Horlett), p. 181. 
As Earl Robert is known to have died in the autumn of 1147, the word arunculus does, undoubtedly, fix these events as prior to that date. But is not avunculus a slip of the writer for cognatus? Is not the reference to Earl William rather than to his father, Earl Robert ?" Such a slip is no mere conjecture; the statement that Earl Robert was too avaricious to assist his beloved nephew in his hour of need is not only absolutely contrary to all that we know of his character, but is virtually discredited by the 'Gesta' itself when its author tells us, further on-

Comes deinde Glaornir ut erat regis adversariorum strenuissimus et ad magna quevis struenda paratissimus, iterum atque iterum exercitum comparare, jugi hortaminis et admonitionis stimulo complices suos incitavit; illos minis, istos promissis sibi et pramiis conjugare ; quatinus omnes in unam concordiam, in unum animum conspirati, exercitum e diverso ad idem velle repararent, et collectis undecumque agminibus, vive et constanter in regem insurgerent..$^{15}$

How can such language as this be reconciled with the statement as to Earl Robert's apathy at the very time when Henry's efforts affered him a unique opportunity of pursuing his war against the king? Mr. Howlett does not attempt to meet, or even notice, this objection. Moreover, when the 'Gesta' proceeds to describe Earl William of Gloucester as devoted to his own pleasures rather than to $\mathrm{war},{ }^{16}$ we see that the conduct so incredible in his father would in him be what we might expect.

I will not follow Mr. Howlett in his lengthy argament relative to the knighting of Eustace and Henry, because he himself admits that it is based only on conjecture. ${ }^{17}$ It is sufficient to observe that if the 'romantic ' narrative in the 'Gesta' refers to the events of $1149,^{18}$ then the knighting of Eustace, which is a pendant to that narrative, belongs, as the other chroniclers assert, to 1149. The

14 There is a precisely aimilar slip, by John of Salisbary, in the Historia Pontifucalis (Pertz, xx. 532), where the 'duke' of Normandy is referred to in 1148 as $q u i$ modo rex est (i.e. Henry). Mr. Howlett bimselt hes pointed ont (Academy, 12 Nov. 1887) that the author ' glipped in the words qui modo rex est, and thas transferred to Henry a narrative which assuredly relates to his tather.' The slip in question, as he observed, has sadly misled Miss Norgate.

is Gesta (ed. Howiett), p. 134.

1" Successit in comitatum surm Willolmus flitis surs, senior quidem actate, sed vir mollis, ot thalamorim magis quam militiae appetitor (Gesta, od. Howlett, p. 194).

"Mr. Howlett incidentally claims that knighthood was a necossary preliminary to comital rank, and appeals to the fact that the younger Henry was even carefally knighted before his coronation (Gesta, p. xxii.). But what has he to say to the knighting of Earl Richard of Clare by Henry VI, and more especially to the knighting of Malcolm, already Earl of Huntingdon and king of Scots, by Henry II, in 1159? (Robert of Torigni, p. 203.)

1s Mr. Hoplett esgerts (Gesta, p. 130, note) that 'when Henry-made his better known visit in 1149 his acts were quite different ' from those recorded in the Gesta. But if, as he himself admits, in 1149 Henry visited Devizes on his pray to Carlisle, what more natural than that he ahould pass by Cricklade and Bourton (the two places mentioned in the Gesta), which lay directly on his road? 
statement, I may add, that Henry applied for help to his mother by no means involves, as Mr. Howlett assumes, her presence in England at the time.

I would suggest, then, that the whole hypothesis of this invasion in 1147 is based on nothing more than a confusion in the 'Gesta.' Mr. Howlett, indeed, claims that 'medieral history would simply disappear if the eridence of chroniclers were to be treated in this way, ${ }^{19}$ and detects ' among some modern writers a tendency to incrutious rejection,' \&c..0 But he himself goes out of his way to denounce, in this connexion, as a 'blundering interpolation' a passage in John of Hexham, which he assigns to notes being 'carelessly misplaced' and 'ignorantly miscopied.' 21 The 'Gesta,' to my knowledge, is by no means immaculate; its unbroken narrative and vagueness as to dates render its chronology a matter of difficulty; and the circumstance that the passage in dispute occurs towards its close renders it impossible to test it ns we could wish by comparison with later portions. The weakness of Mr. Howlett's case is shown by his desperate appeal to 'the exact precedent' set by Fulk Nerra, and no talk about the contrast presented by 'physical science' and that ' fragmentary tale of homan inconsistencies which we term history' can justify the inclusion of this alleged invasion as a fact beyond dispute in so formal and authoritative a quarter as the preface to a Rolls volume.

\section{The alleged debate on Dancyeld in 1168.}

The great importance attached by historians to the financial dispate at the council of Woodstock in 1163 renders it desirable that the point at issue should be clearly stated and understood. As I venture to believe that the accepted view on the matter in dispute is erroneous, I here submit the reasons which have led me to that conclusion. 'Two most important points,' writes Dr. Stubbs, 'stand out' on this occasion: (1) 'this is the first case of any express opposition being made to the king's financial dealings since the Conquest ;' (2) 'the first fruit of the first constitutional opposition is the abolition of the most ancient property tax [danegeld] imposed as a bribe for the Danes.' ${ }^{22}$ It is with the second of these points that I propose specially to deal.

The passage which forms our best evidence is found in Grim's Life of St. Thomas,' and its relative portion is as follows:-

1. Preface to Gesta, p. xx.

$=$ Preface to Gesta (ut supra), p. xri.

z Early Plantagenots, pp. 69, 70. So too Mirs Norgate: 'It seems, therefore, that for the first time in English history since the Norman Conquest the right of the nation's representatives to oppose the financial demands of the crown was asserted in the council of Woodstock, and asserted with such success that the king was obliged not merely to absndon his project, but to obliterate the last trace of the tradition on which it was tounded ' (Angevir Kings, ii. 16). 
Movetur quæstio de consuetudine quadam quae in Anglia tenebatur. Dabantur de hida bini solidi ministris regis qui vicecomitum loco comitatns servabant, quos voluit rex conscribere fisco et reditibus propriis associare. Cui archiepiscopus in faciem restitit, dicens, non debere eos exigi pro reditibus, ' nec pro reditu,' inquit, 'dabimus eos, domine res, salro beneplacito vestro : sed si digne nobis servierint ricecomites, et servientes vel ministri provinciarum, et homines nostros manutenuerint, nequaquam eis deerimus in auxilium.' Rex autem aegre ferens archiepiscopi responsionem, 'Per oculos Dei,' ait, 'dabuntur pro reditn, et in scriptura regis scribentur.'

On this passage Dr. Stubbs thus comments :-

A tax so described can hardly have been anything else than the danegeld, which was an impost of two shillings on the hide, and was collected by the sheriffs, being possibly compounded for at a certain rate and paid by them into the exchequer. As the danegeld from this very year 1163 ceases to appear as a distinct item of account in the pipe rolls, it is impossible to avoid connecting the two ideas, even if we may not identify them. Whether the king's object in making this proposition wns to collect the danegeld in full amount, putting an eud to the nominal assess. ment which had so long been in use, and so depriving the sheriffs of such profit as they made from it, or whether he had some other end in view, it is impossible now to determine ; and consequently it is difficult to understand the position taken by the archbishop. ${ }^{23}$

The attempt to identify the payment in dispute with the danegeld does indeed lead to the greatest possible difficulties, and Miss Norgate, who follows closely in Dr. Stubbs's footsteps, is no more successful in answering them; ${ }^{24}$ for, in the first place, the words of Grim do not apply to the danegeld if taken in their natural sense, and in the second the proceeds of the danegeld were already royal revenue, and were duly paid in, as such, at the exchequer. To meet this latter and obrious difficulty Dr. Stubbs suggests that,

as the sums paid into the exchequer under that name [danegeld] were very small compared with the extent of land that paid the tax, it is probable that the sheriffs paid a fixed composition and retained the surplus as wages for their services [\&c. $]^{23}$

So too Miss Norgate urges that the danegeld 'still occasionally made its appearance in the treasury rolls, but in such small amount that it is evident the sheriffs, if they collected it in full, paid only a fixed composition to the crown, and kept the greater part as a remuneration for their own services.' ${ }^{2}$ Now this suggestion

- Const. Hist.i.462; so too Early Plantagenets, pp. 68-70; and Select Charkers, p. 29, where it is described as 'Henry's proposal to appropriate the sherifis' share of danegeld.'

it Angetin Kings, ii. 15-16.

is Early Plantagenets, p. 69.

- Bat the Auctor Anonymus makes it clear that the king was not asking for the belance of the sums raised, but for the entirety: duw illi solidi . . si in unum conferuntur immersum efficere passtint cumulum. 
raises the whole question as to the revenue from danegeld. We are told that ' the danegeld was a very unpopular tax, probably because it was the plea on which the sheriffs made their greatest profit . . . having become in the long lapse of years a mere composition paid by the sheriff to the exchequer, while the balence of the whole sums exacted on that account went to swell his own income.' 27

As against this view I venture to hold that the danegeld was in no way compounded for, but that every penny raised by its agency was due to the royal treasury, leaving no profit whatever to the sheriff. The test is easily applied : let us take the case of Dorset. The Domesday assessment of this county, according to the late Mr. Eyton, who had investigated it with his usual painstaking accuracy, and collated it with the levy rolls of two years before, was about 2,300 hides. ${ }^{28}$ This assessment would produce, at two shillings on the hide, about $230 l$. Now the actual amount accounted for on the pipe roll of 1130 is $228 l .58$. ; on that of 1156 it is 228l. 58.; and on that of 1162 , the last lery, it is $247 l .58 .{ }^{\text {.9 }}$ There is certainly no margin of profit for the sheriff here. In other counties we find that the proceds of the danegeld in 1130 , 1156 , and 1162, whilst slightly fluctuating, roughly correspond, as indeed they were bound to do, the Domesday assessment remaining unchanged. ${ }^{\text {so }}$ I can therefore find no ground for the alleged discrepancy between the amounts accounted for by the sheriffs and those which the assessment ought to have produced.

This being so, the solitary explanation suggested for Henry's action falls to the ground, and it becomes clear that the payment in dispute could not have been the danegeld, as the proposed change could not increase the amount it produced already. As a matter of fact the last occasion on which danegeld co nomine was levied was in 1162, but to connect that circumstance with the Woodstock dispute of 1163 is an instance of the post hoc propter hoc argument, more especially as the danegeld was not in dispute, still less its abolition. On the contrary, the primate desired to keep things as

"Stubbs, Const. Hist. i. 381, 582.

Dorset Domesday, p. 144.

> Thus accounted for (Rot. Pip. 8 Hen. II) :-

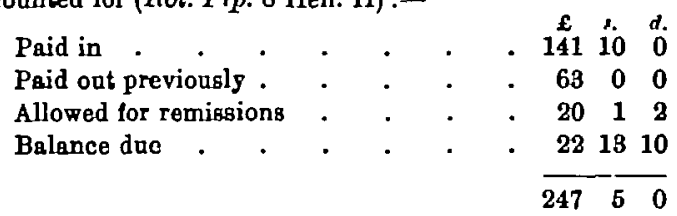

N.B. The roll sums up the remissions as 21 . [sic] 1s. 2d., but the total of the items is 20l. 1s. 2d.

- Oxfordshire, for instance, where the amounts were 239L 9s. Bd., 249l. 6s. idd., 2422. 0s. 10d.; or Wiltshire, where they run B88l. 13s. Od., 389l. 13s. Od., 8881. 11. 11d. 
they were. What, then, was this mysterious payment but the auxilium ricecomitis, or 'sheriff's aid'? Garnier distinctly states that this is what it was," and Grim's words no less unmistakably point to the same conclusion. To institutional students of the twelfth and thirteenth centuries the anxilium vicecomitis is familiar enough. "It was, writes Dr. Stabbs, a 'payment made to the sheriff for his services,' 32 and was, it may be added, a customary charge, varying in amount, ${ }^{3}$ paid over locally to the sheriffs. It may fairly be said to have stood to the danegeld in the relation of rates to taxes.

On this hypothesis the difficulties of the case vanish at once, and Henry's object is made plain. To add this regular annual lery to his own revenues would be all clear gain, and would relieve him pro tanto from the necessity of spasmodic and irregalar taxation. As for the sheriffs and the districts beneath their sway, they were possibly to be left to their own devices to find a substitute for the lost 'aid,' like a modern county council bereft of its wheel tax; for the thought suggests itself that Henry was attempting to reverse the process that we have lately. witnessed, by relieving the taxes at the expense of the rates, instead of the rates at the expense of the taxes. Whether, therefore, the attitude of the primate can be described as 'opposition to the ling's will in' the matter of taxation' is perhaps just open to question. He took his stand on the sure ground of existing ' custom,' recognised at that time as binding on all..$^{34}$ One is tempted to discern a grim irony in Henry's action when he promptly proceeded to turn the tables on his old friend by appealing to the aritae consuetudines as obvionsly binding on so rigid a constitutional purist as the primate. J. H. Round.

\section{THE Date OF THE ' PRERogatita REgig.'}

Is the new edition of the Statutes, vol. i. p. 80, the 'Prerogativa Regis' is printed among the statutes of uncertain date, but. in a note we are told that in all the printed copies it is put down as lelonging to $17 \mathrm{Edward}$ II. From a note on page 74 it appears:

In those editions which continue the statutes beyond Edward $\Pi$, several articles have been placed between the reigns of Edward II and Edward III, under the head of 'Certain Statutes made during the reigns of K. Henry 8, K. Edward 1, or K. Edward 2, but uncertain when

"L'Aide al Vescunte, as quoted by Miss Norgate, who observes thereon, "This payment, although describod as customary rather than legal, and called the " sheriff's aid," seems really to have been nothing else than the danegeld. . . . His [Garnier'b] story points directly to the danegeld.'

Const. Hist. i. 882.

n In this detail alone Grim appears to have conlused it with the uniform two shilling rate of the danegeld.

"Thus the statement that he 'declared at Woodstock that the lands of his charch should not pay a penny to the danegeld' (Const. Hist. i. 578) migrepresents bis position by making him repudiate his undoubted obligation. 
or in which of their times.' The number and nature of the articles so classed vary in the several editions.

From a piece of internal evidence I hope to show that the statute cannot possibly belong to the reign of Edward II, and that it most probably was promulgated under Henry III.

Paragraph 18 of the statute runs as follows:

Item Rex (habeat) omnia catalla dampnatorum felonum et fugitivorum, ubicunque inventa fuerint, et (si) ipsi habeant liberum tenementum, tone illud statim capitar in manu Regis, et Rex habebit omnes exitus ejusdem per unum ennum et unum diem, et tenementum illudd vastabitur et destruetur, de domibus et gardinis, boscis et aliis quibruscunque ad pracdictum tenementum pertinentibus. . .

If we examine the chronicles of the reign of Henry III, we shall find at least one passage to show that the judicial laying waste of lands belonging to felons was customary in his day. In the annals of Dunstaple under 1286 (Ann. Mon. iii. 145) stands the following notice: ct nos habuimus pretium catallorum suorum, et horreum ejus vastavimus; et plegii ejus àmerciati sunt; ct terrac cjus, post annum regis, cesserunt dominis suis. But Britton, writing half a century later, mentions this castom as a thing of the past (Summa de Legibus Angliae, i. 35-86).' It seems probable that Edward I, who was particularly active in the matter of punishmenta (he abolished the death-penalty for prison-breaking, instituted the system of imprisoning for a fixed term, abolished the custom of loading prisoners with chains, \&c.), ${ }^{2}$ did away with the romantic idea of destroying a felon's property. If such be the case, the paragraph of the statute which we are considering could not belong either to the reign of Edward I or Edward II, and the statute itself can be considered as belonging to the reign of Henry III.

E. F. HENDERBon.

\section{THE MISSTNG MANUSCRIPT OF ECCLESTON'S CHRONICLE.}

A refrerence in Leland's ' Comment. de Script. Brit.' p. 298, and some extracts 'ex Chronico cujusdem Thomm Franciscani' in his 'Collectanes' (tomus secundus, vol. iii. p. 341 ; printed in Mon. Franc.i. 547), led Mr. Brewer to suspect the existence of a third manuscript of Eccleston's chronicle, 'De adventu Minorum in Angliam,' besides the Cottonian and York manuscripts. Mr. R. Howlett, the editor of 'Monumenta Franciscana' ii., printed a fragment of the chronicle from a manuscript in $\mathrm{Sir}$ C. Isham's collection at Lamport Hall (called here 'Lamport'). This, however, only supplied most of the

- Et coloums axer do lour tenements, do qi qe unques soint tenus, le an et le jour . . . par issi ge nous ne faceutm estreper ne gaster les tenements ne les boys ne artet les preas, sicum hom woleit ferc on Remembraunce de felonies atteirtes.

- Bee the writer's easay on Ferbrechen und Strafon in England. Berlin, 1889. 